\title{
Transorbital globe sparing penetrating cranial injury with a metallic screw: large cranio-orbital foreign body
}

Nripen Gaur, Pradeep Sharma, Brijesh Takkar, Adarsh Shashni

Department of Ophthalmology, Dr. Rajendra Prasad Centre for Ophthalmic Sciences, All India Institute of Medical Sciences, New Delhi, Delhi, India

\section{Correspondence to} Professor Pradeep Sharma, drpsharma57@yahoo.com

Accepted 8 June 2017

\section{DESCRIPTION}

A 14-year-old man presented to the emergency services following trauma to his left eye (LE) sustained during a battery explosion. The patient was conscious, and oriented in time, space and person, and higher mental functions were preserved. The patient had visual acuity of light perception in his left eye. Head of a metallic screw could be seen on ocular examination and the screw appeared to penetrate the left superior orbit through the upper eyelid (figure 1A). Details of the eyeball could not be visualised, though the cornea appeared opacified. Intraocular pressure could not be assessed on digital palpation due to severe lid oedema. The fellow eye was within normal limits. Ultrasound was avoided in view of suspected open globe injury.
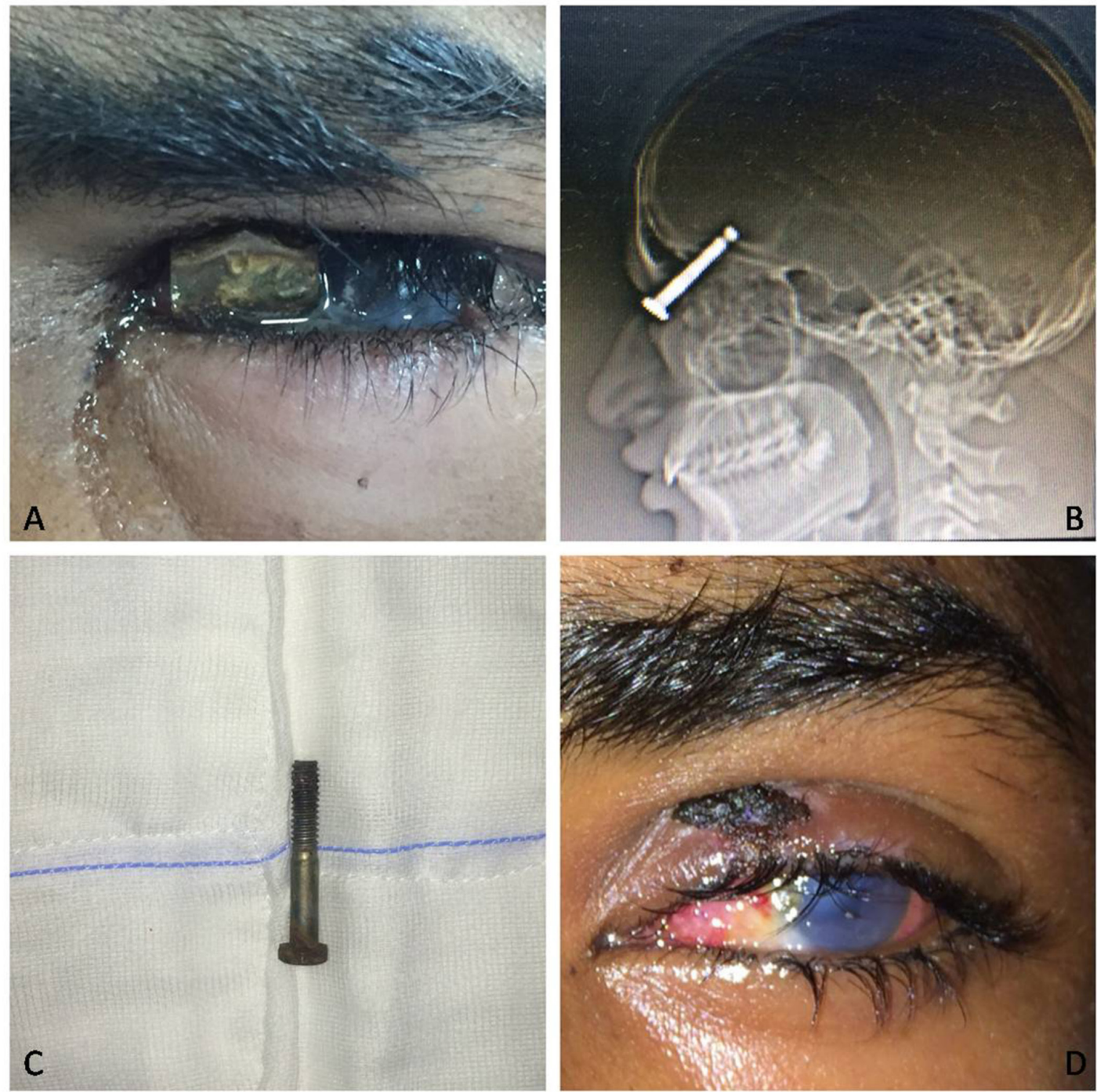

To cite: Gaur N, Sharma $\mathrm{P}_{\text {, }}$ Takkar B, et al. BMJ Case Rep Published Online First: [please include Day Month Year]. doi:10.1136/bcr-2017 221248

Figure 1 (A) Clinical photograph of the left eye showing the presence of head of a metallic screw in the superiormedial orbit. (B) Sagittal section CT image of the head depicting the extension of the metallic screw towards the basifrontal lobe of the left cerebral hemisphere. (C) Image shows the successfully removed metallic screw during surgery (D) postoperative clinical photograph of the left eye showing repaired lid laceration, necrotic conjunctiva and dense corneal oedema. 
An urgent CT scan was advised which revealed the extension of the foreign body (FB) into the basi-frontal lobe of the left cerebral hemisphere (figure 1B). Open-globe injury was presumed and an urgent surgery was planned along with a neurosurgeon for extraction of the FB with globe and eyelid repair.

During surgery, left frontal craniotomy was done and the cranial tissue was retracted by the neurosurgeon. The screw was then isolated from the surrounding structures and was pulled out from the penetration site in the superior orbit (figure 1C). During its extraction, the FB had to be gripped with forceps and slowly 'unscrewed' as it was tightly stuck in the orbital roof. The breach in the orbital roof and the dura mater was repaired by the neurosurgeon. Surprisingly, the globe was found to be intact, though corneal oedema precluded detailed examination of the anterior segment. The conjunctiva appeared to be necrotic possibly due to acidic chemical injury. The upper lid entry wound was sutured in multiple layers. Ultrasound done the following day revealed no abnormality in the posterior segment of the LE. The corneal oedema was persistent though digital ocular pressure seemed normal (figure 1D). The patient was counselled for need of future ocular surface reconstruction followed by keratoplasty, and was immediately referred to corneal surgeon for urgent management of chemical injury. Confidentiality was

\section{Learning points}

- Transorbital penetrating cranial injuries require multidisciplinary approach, and CT is of essence.

- In cases of battery blasts, there is a combination of thermal, mechanical and chemical ocular injury, and such cases need multiple procedures for visual rehabilitation. maintained and only the surgical team had access to patient's details. All unauthorised access to information was prohibited throughout the treatment period.

Penetrating injuries of skull and brain are life threatening and they constitute about $0.4 \%$ of head injuries. ${ }^{1}$ In cases of transorbital intracranial injuries, the orbital roof is the most frequent penetration site owing to its thin wall. ${ }^{2}$ Vertically directed objects may pierce the roof of the orbit and cause frontal lobe damage. A high frequency of vertically oriented injuries has been postulated to be a resultant of an instinctive human tendency to extend the neck backwards as a defensive motion at the moment of trauma. Battery explosion-related ocular injury is from multiple mechanisms. Each mechanism, whether thermal due to heat or mechanical due to solid fragments or chemical due to acid, has the potential to cause irreversible ocular damage and often staged interventions are necessary for optimal results. ${ }^{3}$

Contributors NG, BT and AS contributed to diagnosis, workup, writing the manuscript and performing critical revision. PS holds the overall responsibility to the presentation and contributed in diagnosis and performing critical revision of the manuscript.

Competing interests None declared.

Patient consent Obtained from guardian.

Provenance and peer review Not commissioned; externally peer reviewed.

(c) BMJ Publishing Group Ltd (unless otherwise stated in the text of the article) 2017. All rights reserved. No commercial use is permitted unless otherwise expressly granted.

\section{REFERENCES}

1 Gennarelli TA, Champion HR, Sacco WJ, et al. Mortality of patients with head injury and extracranial injury treated in trauma centers. J Trauma 1989;29:1193-202.

2 Kitakami A, Kirikae M, Kuroda K, et al. Transorbital-transpetrosal penetrating cerebellar injury--case report. Neurol Med Chir 1999;39:150-2.

3 Moore AT, Cheng H, Boase DL. Eye injuries from car battery explosions. Br J Ophthalmol 1982;66:141-4

Copyright 2017 BMJ Publishing Group. All rights reserved. For permission to reuse any of this content visit http://group.bmj.com/group/rights-licensing/permissions.

BMJ Case Report Fellows may re-use this article for personal use and teaching without any further permission.

Become a Fellow of BMJ Case Reports today and you can:

- Submit as many cases as you like

- Enjoy fast sympathetic peer review and rapid publication of accepted articles

- Access all the published articles

- Re-use any of the published material for personal use and teaching without further permission

For information on Institutional Fellowships contact consortiasales@bmjgroup.com

Visit casereports.bmj.com for more articles like this and to become a Fellow 